8. Словарь современных фразеологизмов французского языка. Под ред. Петровой О.В. изд. 5. Москва. Издат-во Лань. 2018

9. Совиньи Ж-П. Европейская лингвистика в современном мире. Сборник научных трудов Серия «Ученые записки» ф-та лингвистики Тартусского Университета. Вып. 7. Тарту. Эстония. 2020

10. Щербатько М.Р. Современные лингвистические школы. Сборник научных статей ф-та филологии и педагогики Пермского Государственного Педагогического Университета. Серия «Труды молодых ученых». Вып. 7. Пермь. 2019

11. Ульман С. Антропонимы и топонимы во французском языке. Сборник научных статей филологического ф-та Вильнюсского Университета. Вып. 15. Вильнюс. 2020

12. Французские сказки. Сборник рассказов под ред. Жегловой А.В. Москва Из-во Агриппиус. 2019

\title{
Осипчук А.Е. \\ Интенциональное содержание речевого жанра положения в военном деловом дискурсе
}

Филиал Военного учебно-научного иентра Военно-воздушных сил «Военновоздушная академия имени проф. Н.Е. Жуковского и Ю.А. Гагарина»

doi: $10.18411 /$ sr-10-08-2021-39

(Россия, Сызрань)

\section{Аннотация}

В статье рассматривается интенциональное содержание речевого жанра положения, функционирующего в военном деловом дискурсе. Автор делает вывод о наличии в тексте положений основной (регламентировать) и дополнительных (приказать, идентифицировать) жанрообразующих интенций, находящих лексическое и грамматическое выражение в специфических языковых единицах.

Ключевые слова: интенция, интенциональное содержание, речевой жанр, положение, военный дискурс.

\section{Abstract}

The article examines the intentional content of the speech genre of the position, functioning in the military discourse. The author concludes that the text contains provisions of the main (regulate) and additional (order, identify) genre-forming intentions that find lexical and grammatical expression in specific linguistic units.

Keywords: intention, intentional content, speech genre, position, military discourse.

Интенция является ключевым понятием в исследовании речевого взаимодействия, которое охватывает все сферы деятельности человека, в том числе и военную.

В.Г. Борботько пишет, что «каждая область человеческой деятельности обладает собственным дискурсом, в котором реализуются способности человека к рефлексии и коммуникации» [2, с. 6]. Дискурс, по определению Н.Д. Арутюновой, - «связный текст в совокупности с экстралингвистическими - прагматическими, социокультурными, психологическими и другими факторами; текст, взятый в событийном аспекте; речь, рассматриваемая как целенаправленное социальное действие, как компонент, участвующий во взаимодействии людей и механизмах их сознания (когнитивных процессах). Дискурс - это речь, «погруженная в жизнь» [7, с. 136-137]. Признаком, позволяющим выделить и обозначить военный деловой дискурс, является военная сфера деятельности, определяющая участников социального взаимодействия и закрепляющая их статусную ориентацию, организующая типизированные коммуникативные ситуации, имеющая культурологические формы особого, строго обозначенного и жестко закрепленного характера, предполагающая нормы и правила использования языка. 
Изучение речевых жанров (далее - РЖ) как дискурсивных образований, функционально-структурные и коммуникативно-прагматические характеристики которых определяются особенностями военного делового дискурса, предполагает их типологизацию. И.В. Уткина в диссертационном исследовании выделяет директивные, организационно-деловые и информационно-справочные военно-деловые РЖ [15, с. 71]. Эти типы объединены и противопоставлены по их коммуникативным целям. Так, директивные жанры являются императивными, побуждают адресата речи к выполнению воли говорящего; организационно-деловые упорядочивают деятельность военнослужащих; информационно-справочные содержат важную для войск информацию [15, с. 72-73]. Внутри данных групп происходит деление жанров на виды, которые различаются своим интенциональным составом: «Каждый жанр предполагает наличие набора интенций, расположенных в заданной последовательности и связанных между собой, объединённых общей интенцией, создающей специфику жанра» [15, с. 60]. Под интенцией мы, вслед за Н.И. Формановской, понимаем коммуникативное намерение, замысел, план действий говорящего [16, с. 125]. Соглашаемся с мнением А.И. Дунева, который пишет, что интенциональное содержание - это «тот аспект смысла высказывания, который включает языковые средства, отражающие замысел, а также те компоненты высказывания, в которых отражена связь замысла с элементами речевой ситуации» [3].

Рассмотрим интенциональное содержание такого организационно-делового РЖ военного делового дискурса как положение.

Положение - РЖ, предназначенный для организации и регулирования бытовой, учебно-профессиональной и боевой деятельности военнослужащих [См.: 15, с. 71]. По словам И.В. Уткиной, «эти документы устанавливают порядок деятельности войск, военных организаций, подразделений, отдельных военнослужащих» [15, с. 72]. Исследователь подчеркивает основную функцию организационно-деловых РЖ, которую обозначил еще Г.М. Стрелковский - «регламентировать жизнь и деятельность войск в различных условиях повседневной жизни и боевой обстановки» [13, с. 132]. Опишем номинацию рассматриваемого РЖ.

Положение - 1) 8. Свод правил, законов по определенному вопросу [11, ст. 1042]; 2) правовой акт (распорядительный служебный документ), устанавливающий основные правила организации и деятельности органа военного управления (подразделения воинской части) [4, с. 48]; 3) письменный официальный документ, детально регламентирующий правовой статус, организацию, порядок деятельности определенных государственных органов, учреждений и их взаимодействие с другими органами и учреждениями, а также гражданами [1, с. 444].

Процедура ступенчатой идентификации лексического значения, разработанная Э.В. Кузнецовой, состоящая «в последовательном сведении слов через идентификаторы к словам с предельно обобщенным характером» [6, с. 36], позволяет описать структуру лексического значения жанровой номинации положение, содержание которого представлено семами: 1) 'объединение' (свод, совокупность правил, норм); 2) 'норма' (правила, законы, регламент); 3) 'порядок' (упорядоченная, направленная деятельность); 4) 'управлять' (руководящий документ); 5) 'массовый' (распространяющийся на всех членов процесса общения).

Идентификатором положения является лексическая единица основнье правила, в содержании которой реализуется специфическая жанроразличительная сема 'наиболее важный, главный'.

Коммуникативной целью регламентирующих жанров является сообщение адресату требований о порядке и способах выполнения определенных действий, побуждение слушателей к осуществлению этих операций только описанными, установленными методами. Подтверждение этой мысли находим в Положении о персональном учёте потерь и погребении погибщего личного состава Красной Армии в 
военное время, где прописано, что обозначенный документ «определяет систему (здесь и далее выделено нами - A.O.) персонального учета потерь на фронтах, порядок погребения погибших и устанавливает правила извещения населения страны о судьбе их родственников - военнослужащих действующей армии» [14, с. 32].

Таким образом, основная коммуникативная цель текстов РЖ положения заключается в констатации правил, обеспечивающих рациональную организацию жизнедеятельности военнослужащих. По этой причине основной жанрообразующей интенцией мы называем интенцию регламентировать.

Рассмотрим семантику РЖ положения, в значении номинации которого нами выделена сема 'наиболее важный'. Данный компонент значения позволяет говорить о положении как о РЖ общего, основополагающего характера, содержание которого предполагает и обуславливает появление иных императивных жанров, раскрывающих проблематику положения как стержневого регламентирующего жанра организационноделового типа.

Тексты, номинированные этим термином, часто представлены в сборниках, характеризующих работу Тыла Красной Армии периода Великой Отечественной войны 1941-1945 гг. В.И. Исаков относит положение к документам боевого управления, предназначенным для нормативного сопровождения процесса формирования и функционирования централизованной системы тылового обеспечения войск [14, с. 2]. Это связано с целью положения как «правового акта, устанавливающего основные правила организации и деятельности органа военного управления (подразделения воинской части)» [4, с. 48]: Положение о главном военно-санитарном управлении Красной Армии [14, с. 89]. Кроме того, описываемый документ определяет функции и организует деятельность субъекта, занимающего определенное должностное место: Положение об армейском интенданте не отдельной армии, входящей в состав фронта, в военное время [14, с. 70].

Основная жанрообразующая интенция РЖ положения реализуется за счет функционирования императивной интенция приказывать (приказать' - велеть, потребовать, не допуская возможности неисполнения' [8, с. 294]).

Частотными средствами ее реализации являются:

- глагол возлагаться ('возложить'- 'сделать ответственным за что-либо' [8, с. 32]): На Управление оборонительного строительства Красной Армии возлагается: 1. Разработка по заданию Генерального штаба Красной Армии вопросов строчтельства новых укрепленных районов, а также достройка и оборудование существующих укрепленных районов $<\ldots>$ [Комсостав, 66];

- глагол ведать, предназначенный для общего обозначения управленческой деятельности ('ведать' - '6. Управлять, руководить' [8, с. 687]: Начальник тыла Красной Арии ведает организачией тыла и регулированием подвоза всех видов снабжения и пополнения к фронтам и эвакуацией в тыл военного имущества, больных и раненых военнослужащих [14, с. 74];

- сочетание нести ответственность ('ответственность' - '1. Обязанность, необходимость давать отчет в своих действиях, поступках и т.n. и отвечать за их возможные последствия, за результат чего-л.' [9, с. 668]): При выполнении перевозок войсковых соединений $u$ частей начальник передвижения несет ответственность: а) за составление плана погрузки воинских эшелонов < .. > [14, с. 103];

- краткое страдательное причастия с императивным значением обязан (обязать' - '1.приказать, предписать' [8, с. 304]): Начальник 
передвижения войск обязан: a) устанавливать совместно $c$ начальником дороги порядок работь железнодорожных узлов и станций в условиях воздушной опасности и требовать от военных комендантов и работников дороги его точного выполнения <... [14, с. 103]; Начальник военных сообщений фронта обязан своевременно извещать органы снабжения фронта о грузах, следующих в адрес распорядительных станций фронта < .. > [14, с. 114].

Дополнительной интенцией положения является интенция идентифицировать ( идентифицировать'- Установить (устанавливать) полное совпадение, соответствие одного предмета, явления и т. д. другому' [10, с. 630]), которая в первую очередь реализуется в процессе дефинирования объекта речи, определения места управляющего органа в ряду подобных ему социальных, иерархически детерминированных структур: Народный комиссариат оборонь Союза ССР, в соответствии со ст. 77 Конституции Союза Советских Социалистических Республик, является общесоюзным Народным комиссариатом Союза Советских Социалистических Республик [5, с. 28]; Главное военно-санитарное управление Красной Армии является центральным органом Народного комиссариата обороны ССР по руководству санитарной служббой Красной Армии [14, с. 89]. Характеристика объекта речи общесоюзный (общий' - '1. Относящийся ко всему, всем, распространяющийся на всех, все, охватывающий всех, все' [9, с. 577]), иентральный (иентральный - 3. Главный, руководящий, связанный с центром (в 5 знач. 'иентр' - 5. Высший орган (органы) управления какой-л. деятельностью); 4. Самый важный и существенный среди других; главный, основной $[12$, с. 641]) содержит указание на специфическую позицию, определяющуюся значениями слов, занимаемую им по отношению к другим функционально тождественным объектам. Этой же функции подчинено использование в текстах документов описываемого РЖ сочетания лексической единицы полномочный представитель с наименованием органа управления, определяющего социальный статус агенса: Начальник передвижения является полномочным представителем Народного комиссариата обороны Союза ССР по руководству передвижением войск и военных грузов [14, с. 102].

Средством выражения интенции идентифицировать становится глагол-связка являться, которая реализуется во всех высказываниях, называющих сущностные характеристики объекта: Автомобильное управление (отдел) фронта (армии) является органом военного совета фронта (армии) по снабжению, учету, распределению, перераспределению и контролю за состоянием и технической эксплуатацией автомобильного парка < ..> [14, с. 266].

Таким образом, основная коммуникативная цель РЖ положения раскрывается в процессе взаимодействия интенций приказывать и идентифицировать. Отмеченная выше сема 'наиболее важный', определяющая семантику номинации положения, обуславливает функционирование названных интенций. Наиболее важная информация об объекте, позволяющая понять его сущность, определить место в ряду подобных ему объектов, реализуется интенцией идентифицировать, для обозначения основных закрепленных за носителем деятельности функций служат конструкции, организованные предикатными словами с императивным значением.

$$
* * *
$$

1. Большой юридический словарь / под ред. А.Я. Сухарева, В. Е. Крутских. - М.: ИНФРА-М, 2002. $704 \mathrm{c}$.

2. Борботько В.Г. Принципы формирования дискурса: От психолингвистики к лингвосинергетике. М.: ЛИБРОКОМ, 2011. -288 с. 
3. Дунев А.И. Интенциональность грамматических значений в аспекте речевого воздействия// Стереотипность и творчество в тексте: Сб-к научных трудов. - Пермь, 2004. - URL: http://www.psu.ru/psu/files/0549/05_Dunev.doc (дата обращения: 23.07.2021).

4. Инструкция по делопроизводству в Вооруженных Силах Российской Федерации (ИД-2017) - М.: Республика, 2000. - URL: https://files.stroyinf.ru/Data2/1/4293729/4293729597.pdf (дата обращения: 25.06.2021).

5. Командный и начальствующий состав Красной Армии в 1940-1941 гг. / сост.: Н.С. Тархова (отв.) и др. - М.: Летний сад, 2005. - 271 с.

6. Кузнецова Э.В. Лексикология русского языка. - М.: Высш. шк., 1989. $\square 216$ с.

7. Лингвистический энциклопедический словарь/ гл. ред. В.Н. Ярцева. - М.: Сов. энциклопедия, 1990. -685 c.

8. Русский семантический словарь: в 4-х т. Т. 4/ Под ред. Н.Ю. Шведовой. М.: «Азбуковник», 1998. 922 c.

9. Словарь русского языка: В 4-х т. Т. 2/ Под ред. А.П. Евгеньевой. - М.: Русский язык, 1986. - 736 с.

10. Словарь русского языка: В 4-х т. Т. І / Под ред. А.П. Евгеньевой. - М.: Русский язык, 1985. - 696 с.

11. Словарь современного русского литературного языка: в 16 т. Т. 10/ Глав. ред. В.И. Чернышев. М.-Л., 1960. - 1774 ст.

12. Словарь русского языка: В 4-х т. Т.4 / Под ред. А.П. Евгеньевой. - М.: Русский язык, 1988. - 800 с.

13. Стрелковский Г.М. Теория и практика военного перевода. Немецкий язык/ Г.М. Стрелковский. М.: Воениздат, 1979. - 272 с.

14. Тыл Вооруженных сил в документах: Велик. Отечеств. война (1941-1945 гг.)/ Отв. ред. В.И Исаков. - М., 2000. - 719 с.

15. Уткина И.В. Оптимизация форм речевого общения военнослужащих в учебно-профессиональной сфере: дисс.... канд. филол. наук: 10.02.21. - Тверь, 2006. - 147 с.

16. Формановская Н.И. Речевое общение: коммуникативно-прагматический подход. - М.: Рус. яз., 2002. -213 c.

\section{Свистунова Н.И., Боргоякова Р.Р. \\ Сравнительная характеристика языковых средств, репрезентирующих вкусовые свойства продуктов питания для человека и домашних питомцев в рекламных текстах (на материале английского языка) \\ ФГБОУ ВО «Хакасский государственный университет им. Н.Ф. Катанова»}

(Россия, Абакан)

doi: $10.18411 / s r-10-08-2021-40$

\section{Аннотация}

В статье рассматриваются языковые средства, репрезентирующие вкусовые свойства продуктов питания для человека и домашних питомцев в рекламных текстах. В результате анализа было выявлено, что в рекламе продуктов питания для человека употребляются языковые средства, указывающие на сложные ароматы и вкус, визуальные характеристики продукта, форму и цвет продукта, текстуру и консистенцию, эмоции. В рекламных текстах корма для животных акцентируется информация о составе, качестве, пользе продуктов и призыв заботиться о здоровье домашних питомцев.

Ключевые слова: реклама, языковые средства, продукты питания.

\section{Abstract}

The article deals with the language means, representing tasteful character of food for a human being and for pets in advertisements. As a result of the analysis it was found out that the advertisement for a human being contains language means related to complicated flavor and taste, visual characteristics of products, form and colour of food, texture and consistency, emotions. Advertisements of pet food make emphasis on ingredients, quality, use and appeal to take care of pets.

Keywords: advertisement, language means, food. 